Recent advances in the detection of specific natural organic compounds as carriers for radionuclides in soil and water environments, with examples of radioiodine and plutonium

Santschi, P.H., ${ }^{a^{*}}$ Xu, C., Zhang, S., ${ }^{a}$ Schwehr, K.A., ${ }^{a}$ Lin, P., ${ }^{a}$ Yeager, C.M., ${ }^{b}$ and Kaplan, D.I. ${ }^{c}$ 


\title{
Recent advances in the detection of specific natural organic compounds as carriers for radionuclides in soil and water environments, with examples of radioiodine and plutonium
}

\begin{abstract}
Among the key environmental factors influencing the fate and transport of radionuclides in the environment is natural organic matter (NOM). While this has been known for decades, there still remains great uncertainty in predicting NOM-radionuclide interactions because of lack of understanding of radionuclide interactions with the specific organic moieties within NOM. Furthermore, radionuclide-NOM studies conducted using modelled organic compounds or elevated radionuclide concentrations provide compromised information related to true environmental conditions. Thus, sensitive techniques are required not only for the detection of radionuclides, and their different species, at ambient and/or far-field concentrations, but also for potential trace organic compounds that are chemically binding these radionuclides. GC-MS and AMS techniques developed in our lab are reviewed here that aim to assess how two radionuclides, iodine and plutonium, form strong bonds with NOM by entirely different mechanisms; iodine tends to bind to aromatic functionalities, whereas plutonium binds to $\mathrm{N}$-containing hydroxamate siderophores at ambient concentrations.

While low-level measurements are a prerequisite for assessing iodine and plutonium migration at nuclear waste sites and as environmental tracers, it is necessary to determine their in-situ speciation, which ultimately controls their mobility and transport in natural environments. More importantly, advanced molecular-level instrumentation (e.g., nuclear magnetic resonance (NMR) and Fourier-transform ion cyclotron resonance coupled with electrospray ionization (ESI-FTICRMS) were applied to resolve either directly or indirectly the molecular environments in which the radionuclides are associated with the NOM.
\end{abstract}

Keywords: 


\section{Introduction}

44 equilibrate with different phases over time through redox, complexation, sorption, 45 precipitation and microbial reactions with inorganic and organic phases, e.g., specific 46 natural organic matter (NOM) compounds with clustered chelating sites. While there is

47 evidence for natural organic matter bound radionuclides from sequential extraction 48 experiments (e.g., Livens and Baxter, 1988; Qiao et al., 2012), such evidence is often 49 fraught with ambiguity since the results are not very specific and can depend on the 50 nature and order of sequential leaching agents, and prevalence for re-adsorption artefacts

51 to different fractions (Martin et al., 1987; Nirel and Morel, 1990; Hou et al., 2007; Okoro

52 et al., 2012). Thus, it is highly desirable to combine radioanalytical techniques with

53 molecular level organic matter identification techniques in order to pinpoint the organic 54 carrier molecules for specific radionuclides in the environment.

55 The objective of this review is to assess the recent advances in measuring natural 56 organic matter associated radionuclides, ${ }^{129} \mathrm{I}$ and $\mathrm{Pu}$, as well as molecular characteristics 57 of these carriers. Two radionuclides that bond strongly to natural organic matter,

58 plutonium and iodine, are used as examples to demonstrate that radionuclide binding 59 mechanisms to organic matter can differ greatly. Furthermore, the intent of this review is

60 to also demonstrate that it is not adequate or in some cases even important to consider 61 total organic carbon or organic matter when attempting to understand radionuclide-NOM 62 interactions. Instead, advances need to be made to identify the specific reactive moieties 
63 within organic matter that are involved in the bonding. Such information is important

64 because it helps prediction of bonding scenarios when system chemistry changes spatially 65 or temporally. Sensitive techniques are required not only for the detection of 66 radionuclides and their different species at low ambient concentrations prevalent in the

67 far-field, but also for the detection of potential trace organic compounds that chemically 68 bind to these radionuclides. Examples are discussed of studies conducted at radionuclide 69 contaminated field sites. Particular attention is directed at measurements of organically 70 bound radionuclides where specific organic compounds affect iodine (e.g., $\left.{ }^{129} \mathrm{I}\right)$ and

71 plutonium (e.g., ${ }^{239,240} \mathrm{Pu}$ ) speciation and environmental transport. This review does not

72 include an exhaustive description of our understanding of radionuclide interactions with

$73 \mathrm{NOM}$, instead it focuses on recent findings related to $\mathrm{Pu}$ and I. Previous reviews of $\mathrm{Pu}-$

74 NOM interaction have been provided by Neu et al. (2002) and I-NOM interaction have 75 been provided by Kaplan et al. (2014a).

\section{Iodine}

\subsection{Analytical methods to determine ${ }^{129} I$ and ${ }^{127} I$ concentration and speciation}

Iodine (I) exists in multiple oxidation states in the form of organic (org-I) and 80 inorganic species (iodide, $\mathrm{I}^{-}$, and iodate, $\mathrm{IO}_{3}{ }^{-}$) in aquatic systems, leading to complex 81 biogeochemical cycling of stable iodine, ${ }^{127} \mathrm{I}$, and its long-lived isotope, ${ }^{129} \mathrm{I}$, a major by82 product of nuclear fission (reviewed by Kaplan et al., 2014a). In order to assess the 83 distribution of ${ }^{129} \mathrm{I}$ and stable ${ }^{127} \mathrm{I}$ in environmental systems on a regular basis, a sensitive 84 and rapid method was developed, enabling us to simultaneously determine isotopic ratios $85\left({ }^{129} \mathrm{I} /{ }^{127} \mathrm{I}\right)$ and I speciation via inexpensive GC-MS (Fig. 1, also see Zhang et al., 2010). 86 Basically, iodide concentrations are quantified after being derivatized to 4-iodo-N,N87 dimethylaniline. Total inorganic iodine (the sum of iodide and iodate for most 88 environmental samples) are determined by a two-step chemical process: first iodate is 89 reduced to iodide and followed by oxidation and derivatization steps of iodide. Thus 90 iodate is calculated as the difference of total inorganic iodine and iodide. Total iodine,

91 including the sum of iodide, iodate and organo-iodine, is determined by converting 92 organo-iodine into inorganic-iodine via combustion with $\mathrm{V}_{2} \mathrm{O}_{5}$ under $\mathrm{O}_{2}$ stream and 93 following the way of measuring total inorganic iodine. Organo-iodine is then calculated 
94 by the difference between total iodine and total inorganic iodine. Differentiating ${ }^{129}$ I from

$95{ }^{127} \mathrm{I}$ in each species $\left({ }^{129} \mathrm{I}^{-},{ }^{129} \mathrm{IO}_{3}^{-}\right.$and ${ }^{129}$ organo-iodine) is obtained by applying mass-to96 charge ratio of 247 and 249 filters, and integrating the appropriate peaks in the 97 chromatogram, for the derivative products of ${ }^{127} \mathrm{I}$ and ${ }^{129} \mathrm{I}$ iodinated $\mathrm{N}, \mathrm{N}$-dimethylaniline, 98 respectively. This method has a detection limit of $0.04 \mu \mathrm{g} / \mathrm{L}, 0.14 \mu \mathrm{g} / \mathrm{L}$ and $0.35 \mu \mathrm{g} / \mathrm{L}$ 99 for ${ }^{127} \mathrm{I}^{-},{ }^{127} \mathrm{IO}_{3}{ }^{-}$and organo- ${ }^{127} \mathrm{I}$, respectively. The detection limit of total ${ }^{129} \mathrm{I}$ is 73 $100 \mathrm{mBq} / \mathrm{L}$, which is far below the ${ }^{129} \mathrm{I}$ far-field concentration in many DOE sites (e.g., 101 Hanford Site and Savannah River Site (SRS)).

102 In addition to the GC-MS method, a pH-dependent solvent extraction along with 103 combustion paired with accelerator mass spectrometry (AMS) was developed to 104 measure ambient levels of ${ }^{129} \mathrm{I}^{127} \mathrm{I}$ isotope ratios and the speciation of ${ }^{129} \mathrm{I}^{(-}, \mathrm{IO}_{3}^{-}$, and 105 organo-I) (Schwehr et al., 2014). AMS enables ${ }^{129}$ I speciation measurement at much 106 lower concentrations $\left(<10^{-12} \mathrm{M}\right)$ than GC-MS $\left(10^{-9}-10^{-10} \mathrm{M}\right) .{ }^{129} \mathrm{I}$ concentration and 107 speciation in the contaminated groundwater collected from SRS were determined via 108 both approaches (GC-MS vs. AMS) with consistent results.

\section{$109 \quad 2.2$ Iodine speciation in the natural environment}

110 Results using a novel GC-MS method demonstrated that the mobility of ${ }^{129}$ I depends 111 greatly on speciation and its concentration, $\mathrm{pH}$, and sediment redox state, with 112 equilibration times of up to 12 weeks (e.g., Xu et al., 2011a, 2015; Zhang et al., 2011, 113 2014; Emerson et al., 2013; Schwehr et al., 2014). For instance, at ambient 114 concentrations $\left(\sim 10^{-7} \mathrm{M}\right), \mathrm{I}^{-}$and $\mathrm{IO}_{3}^{-}$are significantly retarded by sorption onto mineral 115 surfaces and covalent binding to NOM, while at concentrations traditionally examined in 116 laboratory sorption studies (i.e., $10^{-4} \mathrm{M}$ or higher), $\mathrm{I}^{-}$appears to have negligible sorption 117 to soils and to travel along with the groundwater (Zhang et al., 2011) (Fig. 2). Iodate 118 removal from the mobile aqueous phase can also occur through incorporation into $\mathrm{CaCO}_{3}$ 119 crystal lattice, which was demonstrated under field conditions at the Hanford Site, in 120 eastern Washington, USA (Xu et al., 2015; Zhang et al., 2013a, 2013b). Iodide and iodate 121 interactions with NOM can lead to covalent binding of I to active sites of aromatic carbon 122 moieties on the particle surface (Xu et al., 2011b, 2012, 2013). Iodine association with 123 NOM is important in sediments, even when organic carbon concentrations are very low 124 (e.g., $<0.2 \%$ at Hanford Site) (Xu et al., 2015; Zhang et al., 2013a, 2013b). 
125 Removal of iodine from groundwater through interaction with NOM is complicated 126 by the release of mobile organo-I species (Xu et al., 2011a, 2011b, 2012, 2013). In a field 127 study evaluating iodine interactions with wetland soils at the SRS, South Carolina, USA 128 it was shown that a small fraction of NOM promoted the mobility of iodine by forming 129 mobile organo-I species (Xu et al., 2011a, 2011b, 2012, 2013), a process that we 130 numerically simulated using Michaelis-Menton-type coupled kinetic uptake and redox131 reactions (Chang et al., 2014). Field and laboratory studies (Kaplan et al., 2011, 2014;

132 Otosaka et al., 2011; Schwehr et al., 2014; Zhang et al., 2013a, 2013b; Xu et al., 2015) 133 evaluated the cause for steady increases in groundwater ${ }^{129} \mathrm{I}$ concentrations (up to $37 \mathrm{~Bq}$ $134 \mathrm{~L}^{-1}$, three orders of magnitude greater than ${ }^{129} \mathrm{I}$ limits of $0.037 \mathrm{~Bq} \mathrm{~L}^{-1}$ in drinking water) 135 emanating from radiological disposal basins at the SRS. These studies indicated that an 136 increase of $0.7 \mathrm{pH}$ units in groundwater over 17 years may explain the observed increases 137 in groundwater ${ }^{129}$ I concentrations.

138 Iodine speciation, as opposed to only total I, of the stemflow and throughfall 139 rainwater was for the first time measured in two types of forests of Japan (deciduous and 140 coniferous forests). Not only did total I get concentrated in the rainwater along its 141 pathway from the open air, through the canopy, and along the tree stem, but also it slowly

142 transformed from being dominated by inorganic species, to being dominated by organic 143 species. Such I speciation data provide important information for understanding ${ }^{129} \mathrm{I}$ 144 mobility and transport in the Fukushima Prefecture (Xu et al., 2016). Such data are 145 necessary for conducting dose reconstruction estimates of ${ }^{131} \mathrm{I}$, a short lived radioisotope $146\left(\mathrm{t}_{1 / 2}=8\right.$ days $)$ that could not be readily and extensively measured in real time after the 147 Fukushima Daiichi Nuclear Power Plant accident.

148 Species transformations were also noted in the ${ }^{129}$ I plume in F-Area, SRS (Otosaka et 149 al. 2011). The speciation of ${ }^{129}$ I was primarily iodide near the source term, an unlined 150 basin that received radioactive waste from a uranium reprocessing facility. As the ${ }^{129} \mathrm{I}$ 151 moved along its $0.7 \mathrm{~km}$ path towards a wetland, the ${ }^{129} \mathrm{I}$ speciation tended to include 152 greater percentages of iodate and organo-I. These changes were attributed to 153 concomitant increases in groundwater $\mathrm{pH}(\mathrm{pH} 3.2$ to 6.8) and dissolved organic carbon 154 concentrations ( 5 to $60 \mu \mathrm{M}$ ) (Otosaka et al. 2011). Iodine speciation did not change in a 155 manner that could be explained by the changes in groundwater Eh (650 to $360 \mathrm{mV}$ ). 


\subsection{Iodine interactions with microbes}

Bacteria from a ${ }^{129}$ I-contaminated aerobic aquifer at the F-area of SRS can intracellularly accumulate $\mathrm{I}^{-}$at environmentally relevant concentrations $\left(10^{-7} \mathrm{M}\right)$, but account for only a minor fraction of total added iodide (0.2-2.0\%) (Li et al., 2011; Schwehr et al. 2009), which can not explain the high fraction (up to $50 \%$ of total I) of

161 organo-I in groundwater (Otosaka et al., 2011; Schwehr et al., 2014; Zhang et al., 2014).

162 This is in contrast to marine bacteria which can accumulate up to $50 \%$ of total added

163 iodide ( $\mathrm{Li}$ et al., 2012a, 2012b 2014,). Additionally enzymatic oxidation of $\mathrm{I}^{-}$may 164 provide another pathway for iodination of NOM (Li et al., 2012a, Xu et al., 2011a, 165 2011b) through superoxide ( $\mathrm{Li}$ et al., 2014), and organic acid production ( $\mathrm{Li}$ et al., 166 2012b).

\subsection{Spectroscopic instrumentation to characterize organo-iodine compounds}

168 Alongside the published analytical methods to determine I concentration, speciation, 169 and isotopic ratios, the molecular environment of I in NOM was explored using a series 170 of advanced spectroscopic instrumentation. ${ }^{127}$ I concentration in sequentially extracted

171 fractions of two SRS soils were measured and statistically compared to various organic

172 components determined by ${ }^{13} \mathrm{C}$ DPMAS NMR and solution state ${ }^{1} \mathrm{H}$ NMR. The

173 correlative analysis indirectly revealed the molecular nature of iodine binding

174 environment (Xu et al., 2012): radioiodine was closely associated with the aromatic

175 groups of macromolecules containing esterified products of phenolic and formic acids or

176 other aliphatic carboxylic acids, amide functionalities, quinone-like structures activated

177 by electron-donating groups (e.g., $\mathrm{NH}_{2}$ ), or hemicellulose-lignin-like complexes with

178 phenyl-glycosidic linkages. Additionally, with the help of ESI-FTICRMS, (Xu et al.,

179 2013) were not only able to capture the subtle molecular variation during the enzymatic

180 (lactoperoxidase catalyzed iodide oxidation at $\mathrm{pH}$ 8-9) and non-enzymatic iodination

181 (iodide oxidation by $\mathrm{MnO}_{2}, \mathrm{FeCl}_{3}, \mathrm{Fe}_{2} \mathrm{O}_{3}, \mathrm{H}_{2} \mathrm{O}_{2}$, NOM at acidic $\mathrm{pH}$ etc. and iodate

182 reduction by $\mathrm{MnCl}_{2}, \mathrm{FeCl}_{2}$ and $\mathrm{NOM}$ at acidic $\mathrm{pH}$ ) of $\mathrm{NOM}$ (Fig. 3a), but also resolve

183 the molecular characteristics of organo-I by displaying their formulas in the van Krevelen

184 diagrams(Fig. 3b-d). Peak-to-peak comparison of the ESI-FICRMS spectra of the NOM

185 sample before and after iodination reactions revealed the reactive sites which were

186 involved in the reactions and those sites to which iodine was added through electrophilic 
187 substitution. . There was direct molecular information concerning the features of organo188 iodine compounds: 1) iodination of NOM is mono-substitution; 2) 91\% of organo-iodine 189 compounds were chemically-modified during the iodination process (i.e., only $9 \%$ of the

190 cases were one iodine 'conservatively' replacing one hydrogen without any change of the 191 adjacent molecular structures; 3) organo-iodine compounds were distributed and ranked

192 in the order of abundance, in the regions of unsaturated hydrocarbons, lignins and protein;

193 4) $\mathrm{O} / \mathrm{C}$ values were mostly lower than 0.4 , and more than half ( $53 \%)$ of total identified

194 organo-iodine compounds have the $\mathrm{O} / \mathrm{C}$ values less than 0.2 , suggesting such organo-

195 iodine species might have relatively low hydrophilicity and less mobility; 5) 69\% of the

196 identified organo-iodine species contained nitrogen, which likely was present as ring-

197 activating functionality (e.g., $-\mathrm{NH}_{2}$ or $-\mathrm{HNCOR}$ ) and thus enhancing the nucleophilicity

198 of the aromatic ring for iodine to attack. ESI-FTICRMS, for the first time, directly

199 revealed the molecular reaction mechanisms of iodine sequestration into NOM as well as

200 the structure and nature of resulting organo-iodine compounds.

\section{Plutonium}

\subsection{Natural Organic Matter May Attenuate or Enhance Plutonium Transport}

The human and environmental risks associated with plutonium $(\mathrm{Pu})$ disposal, remediation stem mainly from very long half-life of several $\mathrm{Pu}$ isotopes. Due to the surface-mediated reduction of $\mathrm{Pu}(\mathrm{V})$ and $\mathrm{Pu}(\mathrm{VI})$ species to $\mathrm{Pu}(\mathrm{IV})$ by many minerals (e.g., goethite, hermatite, magnetite, etc.) (Conroy et al., 2016) as well as NOM

211 (Roberts et al., 2008), can reduce higher oxidation states of plutonium to more stable

$212 \mathrm{Pu}(\mathrm{IV})$, it has also been suggested that natural organic matter can stabilize sorbed $\mathrm{Pu}$ on

213 goethite (Tinnacher et al., 2015) and prevent desorption. Solubility of polynuclear $\mathrm{Pu}(\mathrm{IV})$

214 would be enhanced, however, by humic substances (Marsac et al.,2014).

215 As a result, when natural organic matter is low, Pu mobility is low as well. For

216 example, $<10 \%$ of total $\mathrm{Pu}$ in the low organic matter-containing groundwater $(<0.2$

$217 \mathrm{mg} / \mathrm{L})$ was mostly associated with inorganic colloid fractions $(>20 \mathrm{~nm})$ at the Nevada 
218 National Security Site (NNSS). However, Pu seemed to be more mobile at the Rainer

219 Mesa tunnel complex at NNSS where $>65 \%$ of the total $\mathrm{Pu}$ was associated with

220 dissolved organic matter, at 15-19 mg/L DOM (Conroy et al, 2016 and references

221 therein).

222 In sediments collected from a region of SRS close to a contaminated wetland and a 223 groundwater plume, a significant correlation between $\mathrm{Pu}$ and sediment NOM

224 concentrations suggested Pu immobilization by N-containing NOM compounds (Xu et

225 al., 2014, 2015, 2016). In contrast, previous studies reported $\mathrm{Pu}$ can be transported

226 several kilometers in surface waters, in the form of inorganic (Kersting et al., 1999;

227 Novikov et al., 2006) or organic colloids (Santschi et al. 2002). For example, through

228 field studies and laboratory experiments, Santschi et al. (2002) revealed that $10-60 \%$ of

229 the re-mobilized Pu from contaminated soils to streams in storm runoffs, pond discharge

230 and wind dispersion events at Rocky Flats Environmental Technology Site (Colorado

231 USA) was associated with colloidal organic macromolecules. It has been demonstrated

232 that NOM compounds have high affinity for metal ions and thus strongly sorb to iron

233 oxide minerals that are usually abundantly present in the soil and sediments, and further

234 alter the surface characteristics. NOM with different functionalities that bind Pu might

235 interact differently with the same mineral phase, thus affecting Pu immobilization/re-

236 mobilization. For instance, addition of desferrioxamine B (DFOB) to montmorillonite

237 enhanced $\mathrm{Pu}$ immobilization (i.e., sorption to montmorillonite) as Pu-DFOB complex

238 accumulated in the interlayer of montmorillonite. Contrary to this, when humic acid and

239 fulvic acid were present, they strongly decreased $\mathrm{Pu}$ (IV) sorption to montmorillonite due

240 to formation of organic aqueous complexes (Boggs et al., 2015). The stability constants

241 of such $\mathrm{Pu}-\mathrm{NOM}$ complexes is often much stronger than those of $\mathrm{Pu}$ hydrolysis products

242 (Zimmerman et al., 2010), yet controlled by several environmental factors such as $\mathrm{pH}$ and

243 ironic strength. Therefore, it is likely the integrated interactions in a binary (Pu-NOM) or

244 ternary system (mineral phase- NOM- Pu) that ultimately determines the fate of Pu. Four

245 mechanisms for NOM influencing the environmental mobility of Pu have been

246 suggested: 1) formation of ternary complexes (mineral phase- NOM- Pu) on immobile

247 surfaces; 2) formation of immobile binary complex (Pu sequestration to NOM intrinsic

248 colloids/aggregates); 3) formation of mobile Pu-NOM complex; 4) formation of ternary 
249 complexes on mobile inorganic colloids (Conroy et al., 2016). Thus, it is necessary to 250 obtain detailed knowledge of various geochemical factors causing Pu fixation and re251 mobilization in the presence of NOM, particularly at low Pu concentration $\left(10^{-12}-10^{-18}\right.$

252 M) in the far-field of DOE sites.

\subsection{Characterizing Pu-NOM Interactions at Ambient Concentrations}

255 Unfortunately, for analytical convenience, most laboratory Pu-NOM interaction

256 experiments are often performed at $\mathrm{Pu}$ concentrations that greatly exceed those observed

257 in contaminated environments, and the results are then simply extrapolated to ambient

258 environmental conditions. However, this assumption may be unrealistic due to the

259 availability of limited surface-mediated oxidation-reduction reactions sites and strong $\mathrm{Pu}-$

260 binding sites, and $\mathrm{Pu}$ (IV) tends to form polymeric or colloidal Pu-oxide particles (i.e.,

261 intrinsic colloids) at higher concentrations (Zhao et al., 2016)

262 The strategy to resolve this issue is to use a suites of techniques including solvent 263 extraction, ultrafiltration, radiolabelling and isoelectric focusing (IEF) electrophoresis,

264 followed by alpha-counting or ICP-MS determination to obtain natural organic 265 macromolecules that are complexing and immobilizing/remobilizing Pu (Figs. $4 \mathrm{a}$ and $4 \mathrm{~b}$, 266 also see $\mathrm{Xu}$ et al., 2008, 2015b, 2016). This lengthy procedure (Fig. 4a) had to be 267 repeated many times and the Pu-carrying macromolecules had to be accumulated to an 268 amount sufficient for further analysis. The strategy is mainly to concentrate Pu-NOM

269 from bulk soil or sediment to the extent that the mobile Pu fraction, which usually only 270 accounts for a minor fraction of the total bulk sedimentary $\mathrm{Pu}$ and the associated organic 271 carbon ligands (e.g., $0.07 \%$ and $0.55 \%$ of the total sedimentary $\mathrm{Pu}$ and $\mathrm{OC}$, respectively, 272 in the case of RFETS soil), could be detected by alpha-counting (detection limit: $5.8 \times 10^{-5}$ $273 \mathrm{~Bq}$ for ${ }^{239,240} \mathrm{Pu}$ ) or ICP-MS (detection limit: $0.025 \mathrm{pg} / \mathrm{L}$ for ${ }^{239} \mathrm{Pu}$ ) for $\mathrm{Pu}$, and the 274 extracted and purified IEF fractions could be detected by NMR (10 mg C as desirable 275 carbon amount for solid-state ${ }^{13} \mathrm{C}$ NMR) and ESI-FTICRMS (10 $\mu \mathrm{g}$ C needed). Thus one 276 has to take the bulk Pu and organic carbon concentrations of the soil or sediment into 277 consideration to test the feasibility of detecting associations of Pu with individual NOM 278 compounds. A rule of thumb in selecting soil or sediment for such a purpose is to work 
279 with soil OC concentration of at least $2 \%$, and the concentration of $\mathrm{Pu}$ slightly 280 contaminated (three orders of magnitude higher than global fallout values).

281 Purified Pu-carrying NOM can then be characterized with advanced spectroscopic 282 instrumentation. For example, with solid-state direct-polarization magic angle spinning 283 (DPMAS) ${ }^{13} \mathrm{C}$ NMR, ${ }^{1} \mathrm{D}{ }^{1} \mathrm{H}$ NMR, 2D HSQC NMR, and 2D COSY NMR, Pu(IV) in 284 contaminated surface soils from RFETS was demonstrated to be bound to hydroxamates 285 embedded in cutin degradation products cross-linked to hydrophilic moieties (e.g., 286 polysaccharides) (Xu et al., 2008).

287 For more detailed molecular characterization, formulas obtained via ESI-FTICRMS 288 were assigned to those Pu-carrying macromolecules that originated from the bulk mobile 289 colloidal fraction of soil aggregates from SRS that contained most of the added $\mathrm{Pu}$ (Figs. $290 \mathrm{3a}$ and $3 \mathrm{~b}$ ). These formulas showed that $23 \%$ of them contained nitrogen ( $\mathrm{Xu}$ et al., 291 2015b). A van Krevelen diagram of all formulas as well as the N-containing formulas 292 (Fig. 4c) suggest that these macromolecules are mainly aliphatic (65\% in peak number 293 and $68 \%$ in peak intensity, respectively), with some minor fraction of aromatics. They 294 also covered an overlapping region for all lipid-like, partially protein-like, unsaturated 295 hydrocarbons, lignin-like, and carboxyl-containing (Fig. 4d) aliphatic and/or alicyclic 296 molecules (CCAM). An ESI FTICR-MS spectral comparison between the IEF extract and 297 a siderophore standard (desferrioxamine; DFO) suggested the presence of hydroxamate 298 siderophore functionalities in the IEF extract, indicating that $\mathrm{Pu}$ was most likely 299 incorporated into hydroxamate functionality-containing macromolecules by displacing Fe 300 (III) in hydroxamates that would be facilitated by the higher stability constants between $301 \mathrm{Pu}(\mathrm{IV})$ and $\mathrm{OH}^{-}$or hydroxamate (Boukhalfa et al., 2007, Almagro et al., 2008)

302 Another key and novel finding of this work is that hydroxamate siderophores were 303 detected in both particulate or colloidal phases of the sediments (Xu et al., 2015b), rather 304 than only in the low-molecular fractions $(<1000 \mathrm{Da})$. These hydroxamate siderophore 305 moieties have previously been be overlooked due to extraction and detection difficulties 306 (Gillam et al., 1981). Moreover, hydroxamate siderophore concentrations in the 307 soil/sediment particles or colloidal fractions seem to be a few orders of magnitude greater 308 than those in solution (Ahmed et al., 2014; Xu et al., 2015b). 
312 In summary, NOM can play a significant role in controlling the fate and transport of 313 radionuclides. This can in part be attributed to the extremely high concentration of 314 binding sites in NOM, but also, as this review demonstrates, to the wide assortment of 315 binding sites. Iodine can form extremely strong covalent bonds to NOM, especially to 316 certain aromatic moieties, whereas $\mathrm{Pu}$ can be chelated to hydroxamate compounds. The 317 implication of understanding how radionuclide bind to NOM is that it provides the 318 underpinning for predicting the long-term fate and transport of radionuclides in dynamic 319 systems undergoing temporal and spacial chemical or physical changes. For example, 320 changes in system $\mathrm{pH}$ as a plume migrates from the near field to the far field would be 321 expected to have a very different effect on I-NOM interactions, than to Pu-NOM 322 interactions because of the greater $\mathrm{pH}$-dependent role of microbial processes in the 323 former. Taking these two radionuclides (i.e., I and $\mathrm{Pu}$ ) as examples, NOM largely 324 controlled their biogeochemistry, even at very low NOM levels. Finally, it is important to 325 study these systems under environmentally relevant concentrations for both radionuclide 326 and NOM, since key NOM-radionuclide interaction processes for immobilizing or 327 remobilizing radionuclides were found to be extremely concentration dependent.

328 While low-level measurements are a prerequisite for learning more about 329 environmental tracers as well as for nuclear forensics, we have to go beyond that if we 330 want to learn more about the environmental behavior of radionuclides, and attempt to get 331 their in-situ speciation, which ultimately controls their mobility and transport in natural 332 environments.

\section{Acknowledgements}

335 This work was funded by the U.S. Department of Energy (DOE) Office of Science 336 Subsurface Biogeochemistry Research program (ER65222-1038426-0017532), DOE

337 SBR grant \#DE-ER64567- 1031562-0014364, and DOE SBR award \# DE-SC0014152.

338 This work has also been funded through DOE contract DE-AC09-08SR22470 with 339 Savannah River Nuclear Solutions, LLC. 
342 Ahmed, E., Holmström, S.J.M., 2014. The effect of soil horizon and mineral type on the 343 distribution of siderophores in soil. Geochim. Cosmochim. Acta 131(0), 184-195.

344 Almagro, L., Gomez Ros, L.V., Belchi-Navarro, S., Bru, R., Ros Barcelo, A., Pedren, M. 345 A., 2008. J. Exp. Botany Dec.10, 1-14, doi:10.1093/jxb/ern277.

346 Boggs, M. A.; Dai, Z. R.; Kersting, A. B.; Zavarin, M., Plutonium(IV) sorption to 347 montmorillonite in the presence of organic matter. Journal of Environmental 348 Radioactivity 2015, 141, 90-96.

Boukhalfa, H., Reilly, S.D., Neu, P., 2007. Complexation of Pu(IV) with the natural siderophore desferrioxamine $\mathrm{B}$ and the redox properties of $\mathrm{Pu}(\mathrm{IV})$ (siderophore) complexes. Inorg. Chem. 46(3), 1018-1026.

Chang, H.-S., Xu, C., Schwehr, K.A., Zhang, S., Kaplan, D.I., Seaman, J.C., Yeager, C., 355 Santschi, P.H., 2013. Model of radioiodine speciation and partitioning in organic-rich and organic-poor soils from the Savannah River Site. J. Environ. Chem. Engineering 2, 1321-1330.

Choppin, G.R.; and Du, M., f-Element complexation in brine solutions. Radiochim. Acta 1992, 58/59, 101-104.

Conroy, N. A.; Zavarin, M.; Kersting, A. B.; Powell, B. A., Effect of Natural Organic Matter on Plutonium Sorption to Goethite. Environmental Science \& Technology 2017, 51, (1), 699-708.

Denham, M., Vangelas, K.M., 2008. Biogeochemical gradients as a framework for understanding waste-site evolution. Remediation 19, 5-17.

368 No. PNNL-SA-37974. Pacific Northwest National Laboratory (PNNL), Richland, WA 369 (US). 
370 Gillam, A.H., Lewis, A.G., Andersen, R.J., 1981. Quantitative determination of 371 hydroxamic acids. Anal. Chem. 53(6), 841-844.

372 Hou, X., Aldahan, A., Possnert, G. 2007. Speciation Analysis of Radionuclides in the 373 Environment. NKS-B Speciation project report. NKS-176; ISBN 978-87-7893-242-6.

374 Kaplan, D.I., Denham, M. E., Zhang, S., Yeager, C., Xu, C., Schwehr, K.A., Li, H.P., Ho, 375 Y.-F., Wellman, D., Santschi, P.H., 2014a. Radioiodine biogeochemistry and 376 prevalence in groundwater. Critical Rev. Environ. Sci. Technol. 44(20), 2287-2335.

377 Kaplan, D.I., Roberts, K.A., Schwehr, K.A., Lilley, M.S., Brinkmeyer, R., Denham, 378 M.E., DiPrete, D., Li, H.-P., Powell, B.A., Yeager, C.M., Zhang, S.J., Santschi, P.H., 379 2011. Evaluation of a radioiodine plume increasing in concentration at the Savannah 380 River Site. Environ. Sci. Technol. 45, 489-495.

381 Kaplan, D.I., Xu, C., Huang, S., Lin, Y.M., Tolic, N., Roscioli-Johnson, K.M., Santschi, 382 P.H., Jaffé, P.R., 2016. Unique organic matter and microbial properties in the 383 rhizosphere of a wetland soil. Environ. Sci. Technol. 50, 4169-4177, doi: 384 385 386 10.1021/acs.est.5b05165.

Kaplan, D.I., Zhang, S., Roberts, K.A., Schwehr, K.A., Xu, C., Creeley, D., Ho, Y.-F., Li, H.-P., Yeager, C.M., Santschi, P.H., 2014b. Radioiodine concentrated in a wetland. J. Environ. Radioactivity 131, 57-61.

Kersting, A.B., Efurd, D.W., Finnegan, D.L., Rokop, D.J., Smith, D.K., Thompson, J.L., 1999. Migration of plutonium in ground water at the Nevada Test Site. Nature 397 (6714), 56-59.

392 Kaplan, D.I., Santschi, P.H., Yeager, C.M., 2012a. Iodide Oxidizing Activity of 393 Bacteria from Subsurface Sediments of the Savannah River Site, SC, USA, in 394 Kawaguchi, M., Misaki, K., Sato, H., Yokokawa, T., Itai, T., Nguyen, T.M., Ono, J., 395 Tanabe S. (Eds.), Interdisciplinary Studies on Environmental Chemistry Vol. 6 396 Environmental Pollution and Ecotoxicology. Terra Scientific Publishing Company 397 Tokyo, pp. 89-97.

398 Li, H.-P., Brinkmeyer, R., Jones, W.L., Zhang, S.J., Xu, C., Schwehr, K.A., Santschi, 399 P.H., Kaplan, D., Yeager, C.M., 2011. Iodide accumulation by aerobic bacteria 

isolated from subsurface sediments of a ${ }^{129} \mathrm{I}$-contaminated aquifer at the Savannah River Site, S.C. Applied Environ. Microbiol. 77(6), 2153-2160. K.A., Kaplan, D.I., Santschi, P.H., Hansel, C., Yeager, C.M., 2014. Superoxide production by a manganese-oxidizing bacterium facilitates iodide oxidation. Applied Environ. Microbiol. 80(9), 2693-2699.

Li, H.-P., Yeager, C.M., Brinkmeyer, R., Zhang, S., Ho, Y.-F., Xu, C., Jones, W.L., 408 Schwehr, K.A., Otosaka, S., Kaplan, D.I., Santschi, P.H., 2012b. Organic acids produced by subsurface bacteria enhance iodide oxidation in the presence of hydrogen peroxide. Environ. Sci. Technol. 46, 4837-4844.

Livens, F.R., and Baxter, M.S. 1988. Chemical Associations of Artificial Radionuclides in Cumbrian Soils. J. Environ. Radioactivity, 7, 75-86.

Marsac, R., Banik, N.L., Marquardt, Kratz, J.V., 2014. Stabilization of polynuclear plutonium(IV) species by humic acid. Geochim. Cosmochim. Acta, 131, 290-300.

Martin, J.M., Nirel, P., and Thomas, A.J. 1987. Sequential extraction techniques: Promises and Problems. Mar. Chem., 22, 313-341.

Neck, V., Kim, J.I., 2001. Solubility and hydrolysis of tetravalent actinides. Radiochim. Acta 89, 1-16.

Neu, M.P., 2000. In: Chemical Interactions of Actinides in the Environment. Los Alamos Science 26, 416.

Nirel, P., and Morel, F.M.M. 1990. Pitfalls of sequential extractions. Wat. Res.. 24(8), 1055-1056.

Novikov, A.P., Kalmykov, S.N., Utsunomiya, S., Ewing, R.C., Horreard, F., Merkulov, A., Clark, S.B., Tkachev, V.V., Myasoedov, B.F., 2006. Colloid transport of plutonium in the far-field of the Mayak production association, Russia. Science 314 (5799), 638-641.

Okoro, H.K., Fatoki, O.S., Adekola, F.A., Ximba, B.J., Snyman, R.G. 2012. A Review of Sequential Extraction Procedures for Heavy Metals Speciation in Soil and Sediments. 1:181. doi:10.4172/scientificreports. 181. 
429 Okoro, H.K., Fatoki, O.S., Adekola, F.A., Ximba, B.J., Snyman, R.G. 2012. A Review of 430 Sequential Extraction Procedures for Heavy Metals Speciation in Soil and Sediments. 431 1:181. doi:10.4172/scientificreports. 181.

432 Otosaka, S., Schwehr, K.A., Kaplan, D.I., Roberts, K.A., Zhang, S., Xu, C., Li, S.-P., Ho, 433 Y.-F., Brinkmeyer, R., Yeager, C.M., Santschi, P.H., 2011. Transformation and 434 transport processes of ${ }^{127} \mathrm{I}$ and ${ }^{129} \mathrm{I}$ species in an acidic groundwater plume at the 435 Savannah River Site. Sci. Total Environ. 409, 3857-3865.

436 Qiao, J., Hansen, V., Hou, X., Aldahan, A., Possnert, G. 2012. Speciation Analysis of 437 129I, 137Cs, 232Th, 238U, 239Pu and 240Pu in Environmental Soil and Sediment. 438 Appl. Rad. Isotopes, 70(8), 1698-1708

439 Roberts, K.A., Santschi, P.H.; and Honeyman, B.D., $\mathrm{Pu}(\mathrm{V})$ reduction and enhancement of 440 particle-water partitioning by exopolymeric substances. Radiochim. Acta 2008, 96(9441 11), 739-745.

442 Santschi, P.H., Roberts, K.A., Guo, L., 2002. Organic nature of colloidal actinides 443 transported in surface water environments. Environ. Sci. Technol. 36(17), 3711-3719. 444 Schwehr, K.A., Otosaka, S., Merchel, S., Kaplan, D.I., Zhang, S., Xu, C., Li, H.-P., Ho, 445 Y.-F., Yeager, C.M., Santschi, P.H., ASTER Team., 2014. Speciation of iodine 446 isotopes inside and outside of a contaminant plume at the Savannah River Site. Sci. 447 Total Environ. 497-498, 671-678.

448 Schwehr, K.A., Santschi, P.H., Kaplan, D.I., Yeager, C.M., Brinkmeyer, R., 2009. 449 Organo-iodine formation in aquifer sediments at ambient concentrations. Environ. Sci. 450 Technol. 43, 7258-7264.

451 Simpkins, L. A. Influence of natural organic matter on plutonium sorption to gibbsite. 452 Clemson University, Ann Arbor, MI, 2011.

453 Tinnacher, R.M.; Begg, J.D.; Mason, H.; Ranville, J.; Powell, B.A.; Wong, J.C.; 454 Kersting, A.B.; and Zavarin, M., Effect of Fulvic Acid Surface Coatings on Plutonium 455 Sorption and Desorption Kinetics on Goethite. Environ. Sci. Technol. 2015, 49, $4562776-2785$.

457 Xu, C., Athon, M., Ho, Y.-F., Chang, H.-S., Zhang, S., Kaplan, D.I., Schwehr, K.A., 458 DiDonato, N., Hatcher, P.G., Santschi, P.H., 2014. Plutonium immobilization and re- 
mobilization by soil mineral and organic matter in the far-field of the Savannah River Site, USA. Environ. Sci. Technol. 48, 3186-3195.

Xu, C., Chen, H.M., Sugiyama, Y., Zhang, S., Li, H.-P., Ho, Y.-F., Chuang, C.-Y.,

462 Schwehr, K.A., Kaplan, D.I., Yeager, C., Roberts, K.A., Hatcher, P.G., Santschi, P.H.,

463 2013. Novel molecular-level evidence of iodine binding to natural organic matter from

464 Fourier Transform Ion Cyclotron Resonance Mass Spectrometry. Sci. Total Environ.

$465449,244-252$.

466 Xu, C., Miller, E.J., Zhang, S., Li, H.-S., Ho, Y.-F., Schwehr, K.A., Kaplan, D.I., 467 Roberts, K.A., Otosaka, S., Brinkmeyer, R., Yeager, C.M., Santschi, P.H., 2011a. 468 Sequestration and re-mobilization of radioiodine $\left({ }^{129} \mathrm{I}\right)$ by soil organic matter and possible consequences of the remedial action at Savannah River Site. Environ. Sci. Technol. 45, 9975-9983.

Xu, C., Santschi, P.H., Zhong, J.Y., Hatcher, P.G., Francis, A.J., Dodge, C.J., Roberts, K.A., Hung, C.-C., Honeyman, B.D., 2008. Colloidal cutin-like substances crosslinked to siderophore decomposition products mobilizing plutonium from contaminated soils. Environ. Sci. Technol. 42(22), 8211-8217. Kaplan, D.I., Yeager, C.M., Wellman, D., Santschi, P.H., 2015a. A re-evaluation of radioiodine transformation and migration in the subsurface of Hanford Site. J. Environ. Radioactivity 139, 43-55.

Xu, C., Zhang, S., Ho, Y.-F., Miller, E.J., Roberts, K.A., Li, H.-P., Schwehr' K.A., natural organic matter a sink or source for radioiodine $\left({ }^{129} \mathrm{I}\right)$ at the Savannah River Site? Geochim. Cosmochim. Acta 75, 5716-5735.

Xu, C., Zhang, S., Kaplan, D.I., Ho, Y.-F., Schwehr, K.A., Roberts, K.A., Chen, H.M., Didonato, N., Athon, M., Hatcher, P.G., Santschi, P.H., 2015b. Evidence for hydroxamate siderophores and other N-containing organic compounds controlling ${ }^{239,240} \mathrm{Pu}$ immobilization and remobilization in a wetland sediment. Environ. Sci. Technol. 49, 11458-11467.

Xu, C., Zhang, S., Sugiyama, Y., Nobuhito Ohte. N., Ho, Y.-F., Fujitake, N., Kaplan, D.I., Yeager, C.M., Kathleen Schwehr, K.A., Santschi, P.H., 2016. Factors controlling 
iodine and ${ }^{239,240} \mathrm{Pu}$ concentrations and mobility in soils from the Northwestern Fukushima Prefecture, Japan. J. Environ. Radioactivity 153, 156-166. Xu, C., Zhong, J.Y., Hatcher, P.G., Zhang, S., Li, H.-P., Ho, Y.-F., Schwehr, K.A., 493 Kaplan, D.I., Roberts, K.A., Brinkmeyer, R., Yeager, C.M., Santschi, P.H., 2012. The molecular environment of stable iodine and radioiodine $\left({ }^{129} \mathrm{I}\right)$ in natural organic matter: evidence from NMR. Geochim. Cosmochim. Acta 97, 166-182. Zhang, S., Chen, X., Creeley, D., Ho, Y.-F., Li, H.-P., Grandbois, R., Schwehr, K., Kaplan, D., Yeager, C., Wellman, D., Santschi, P.H., 2013b. Response to comment on "Iodine-129 and Iodine-127 speciation in groundwater at Hanford Site, U.S.: iodate incorporation into calcite". Environ. Sci. Technol. 47, 13205-13206.

Zhang, S., Du, J., Xu, C., Schwehr, K.A., Ho, Y.-F., Li, H.-P., Roberts, K.A., Kaplan, 503 D.I., Brinkmeyer, R., Yeager, C.M., Chang, H.-S., Santschi, P.H., 2011. Concentration dependent mobility, retardation and speciation of iodine in surface sediment from the Savannah River Site. Environ. Sci. Technol. 45, 5543-5549.

Zhang, S., Ho, Y.-F., Creeley, D., Roberts, K.A., Xu, C., Li, H.-P., Schwehr, K.A., Kaplan, D.I., Yeager, C.M., Santschi, P.H., 2014. Temporal variation of iodine concentration and speciation $\left({ }^{127} \mathrm{I}\right.$ and $\left.{ }^{129} \mathrm{I}\right)$ in wetland groundwater from the Savannah River Site, USA. Environ. Sci. Technol. 48, 11218-11226.

Zhang, S., Schwehr, K.A., Ho, Y., Xu, C., Roberts, K.A., Kaplan, D., Brinkmeyer, R., Yeager, C.M., Santschi, P.H., 2010. A novel approach for the simultaneous determination of iodide, iodate, and organo-iodide for ${ }^{127} \mathrm{I}$ and ${ }^{129} \mathrm{I}$ in Environmental Samples Using Gas Chromatography - Mass Spectrometry. Environ. Sci. Technol. 44, 9042-9048.

Zhang, S., Xu, C., Creeley, D., Ho, Y.-F., Li, H.-P., Grandbois, R., Schwehr, K.A., Kaplan, D.I., Yeager, C.M., Wellman, D., Santschi, P.H., 2013a. Iodine-129 and Iodine-127 speciation in groundwater at the Hanford Site, U.S.: Iodate incorporation into calcite. Environ. Sci. Technol. 47, 9635-9642.

Zhao, P.; Begg, J. D.; Zavarin, M.; Tumey, S. J.; Williams, R.; Dai, Z. R.; Kips, R.; Kersting, A. B., Plutonium(IV) and (V) Sorption to Goethite at Sub-Femtomolar to Micromolar Concentrations: Redox Transformations and Surface Precipitation. Environmental Science \& Technology 2016, 50, (13), 6948-6956. 
521 Zimmerman, T. N.; Powell, B. A., Plutonium-humic acid stability constant determination 522 and subsequent surface complexation studies. Geochimica Et Cosmochimica Acta $5232010,74,(12)$, A $1237-\mathrm{A} 1237$.

524

525

526 


\section{Figure captions}

528 Fig. 1. Flow chart of iodine speciation (total iodine, TI; total inorganic iodine, TII; 529 organo-iodine, OI; iodide and iodate) and quantification by GC-MS method after derivation to 4-iodo $\mathrm{N}, \mathrm{N}$-dimethylainine, as well as principle for simultaneous measurement of ${ }^{127} \mathrm{I}$ and ${ }^{129} \mathrm{I}$ at elevated environmental samples (detection limit: $2 \mathrm{pCi}$ ${ }^{129} \mathrm{I} / \mathrm{L}$ for liquid sample and $2 \mathrm{pCi}^{129} \mathrm{I} / \mathrm{g}$ for solid sample) (Zhang et al., 2010). Reprinted with permission from Environmental Science and Technology. American Chemical Society. Copyright 2010.

Fig. 2 Breakthrough curves of tritium and iodide a) and iodate b) in Savannah River Site wetland sediment, FSI-18 (relative concentration $=$ concentration in effluent/ concentration in influent solution). Iodide/iodate applied to the columns at two concentration levels, $7.87 \mathrm{nM}$ and $78.8 \mu \mathrm{M}$. For each species, the two solutions (at high and low concentrations) were both spiked with ${ }^{125} \mathrm{I}$ and ${ }^{127} \mathrm{I}$. Spike solutions $(15-20 \mathrm{~mL})$ were added and then flushed with artificial groundwater for 30 to 45 days (Zhang et al., 2011). Reprinted with permission from Environmental Science and Technology. American Chemical Society. Copyright 2011.

Fig. 3. a) Flow chart of iodination of natural organic matter (NOM) starting from iodide or iodate via enzymatic or non-enzymatic pathways, b) ESI-FTICRMS analysis in negative mode NOM extracted from surface soil of F-Area of Savannah River Site amended without (up) and with (down) I- - through enzymatic reactions c) an example of identification of organo-iodine peak through peak-to-peak comparison between the uniodinated and iodinated NOM spectra and molecular formula assignment; d) van Krevelen diagram of all identified organo-iodine formulas (Xu et al., 2013). Reprinted with permission from Science of the Total Environment. Copyright 2013.

Fig. 4. a) Flow chart of extraction and purification of plutonium-carrying macromolecules from soil or sediment samples; b) isoelectric focusing spectrum showing the $\mathrm{Pu}$ concentration distribution of the macromolecules along the $\mathrm{pH}$ gradient; $\mathrm{c}$ ) van Krevelen diagram showing all 1259 formulas (blue) and the N-containing formulas (red) of the Pu enriched fraction purified via isoelectric focusing experiment; d) Kendrick mass defect (KMD) plot of FTICR-MS peaks on the trend line analyzed by COO KMD analysis (carboxylic-rich alicyclic molecules (CRAM)- double bond equivalent (DBE)/C $=0.30-0.68 ; \mathrm{DBE} / \mathrm{H}=0.20-0.95 ; \mathrm{DBE} / \mathrm{O}=0.77-1.75 ;$ carboxyl-containing aliphatic molecules $(\mathrm{CCAM})=\mathrm{O} / \mathrm{C} 0-0.40, \mathrm{H} / \mathrm{C}$ 0.85-2.00) (Xu et al., 2015b). Environmental Science and Technology. American Chemical Society. Copyright 2015. 
573 Fig. 1.

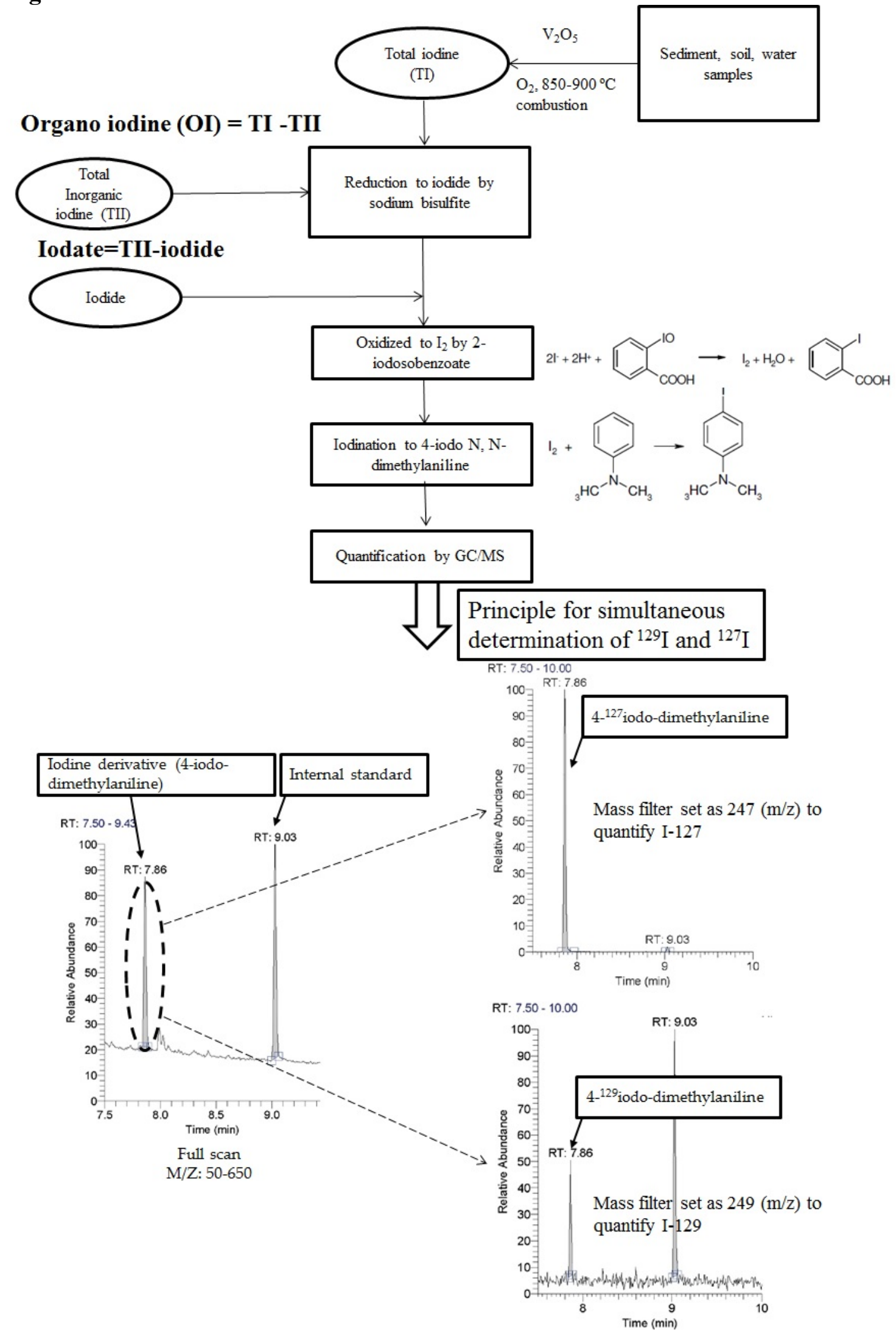



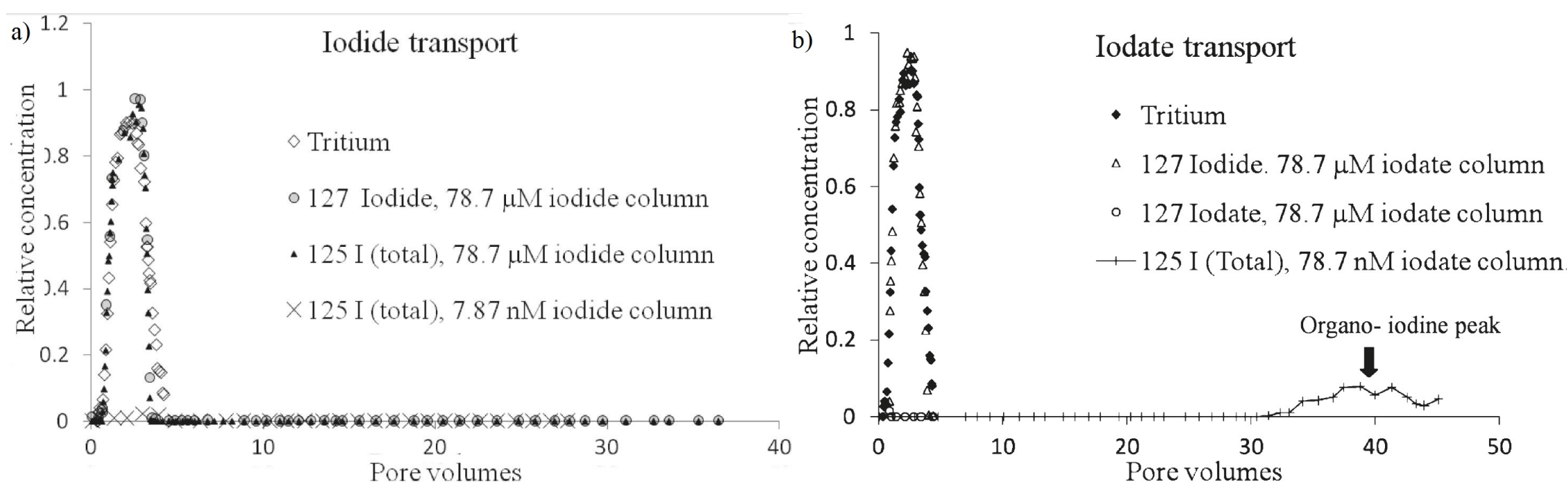

Fig. 2. 


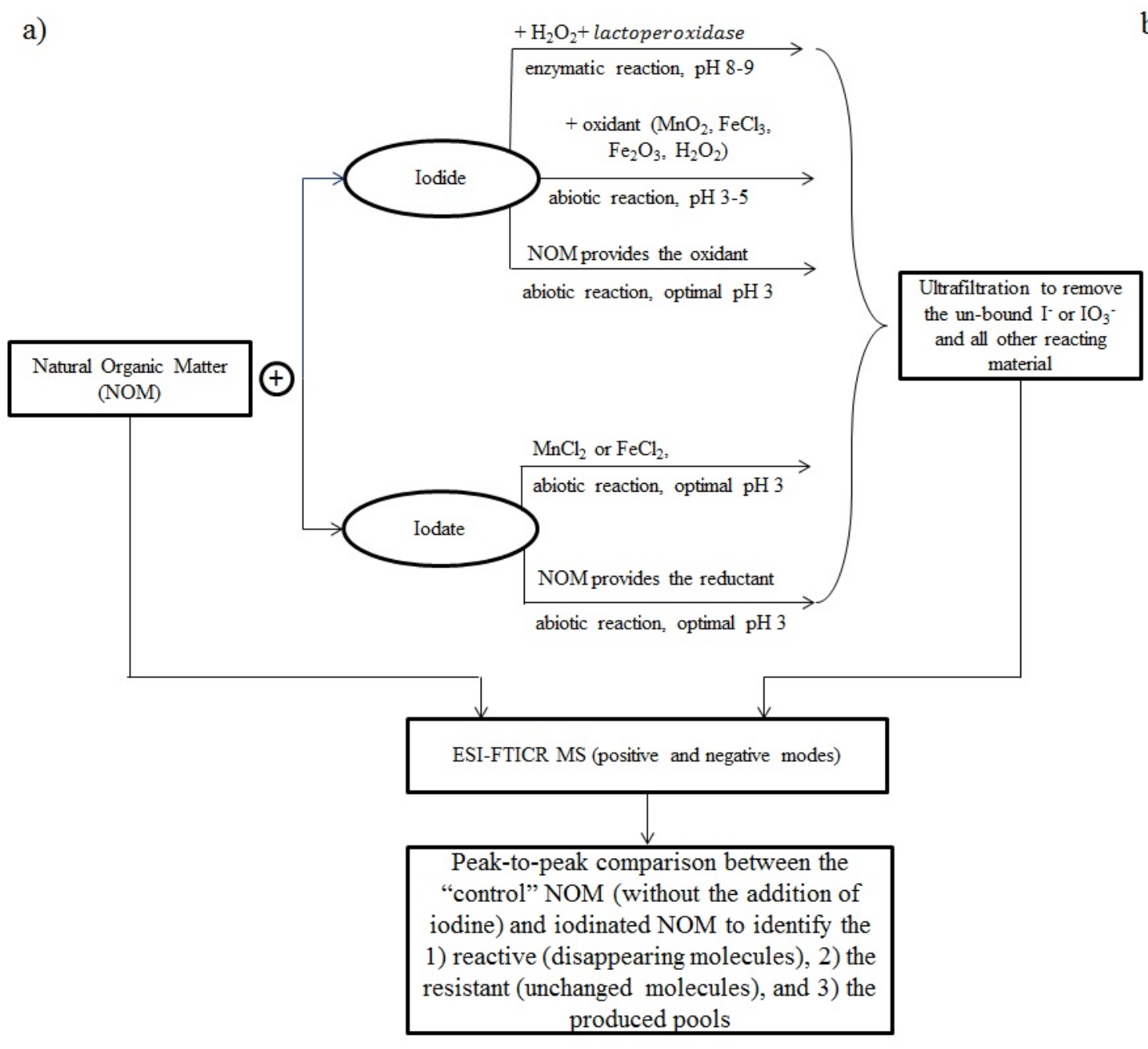

b)

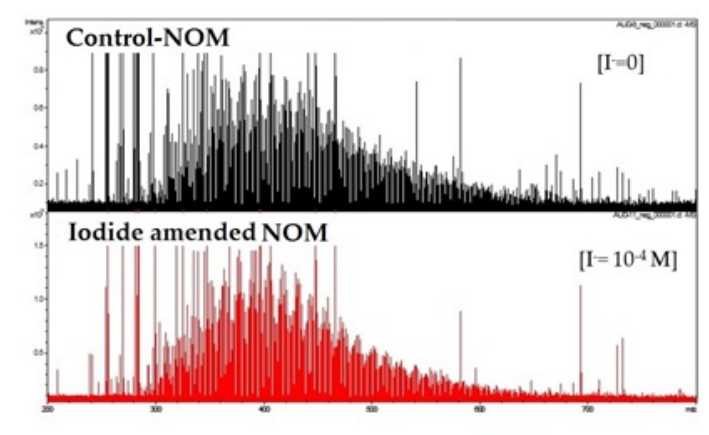

c)

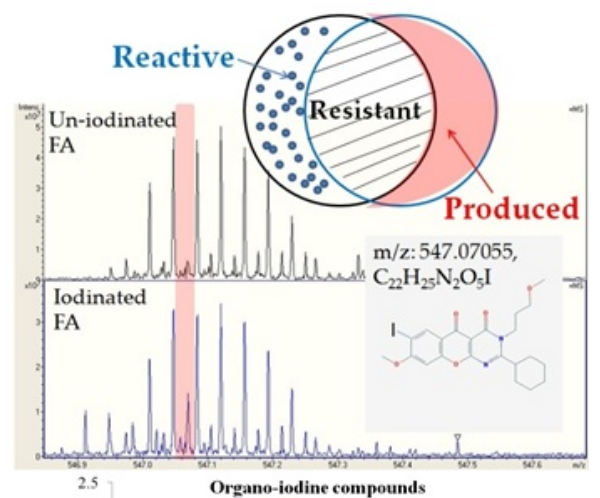

d)

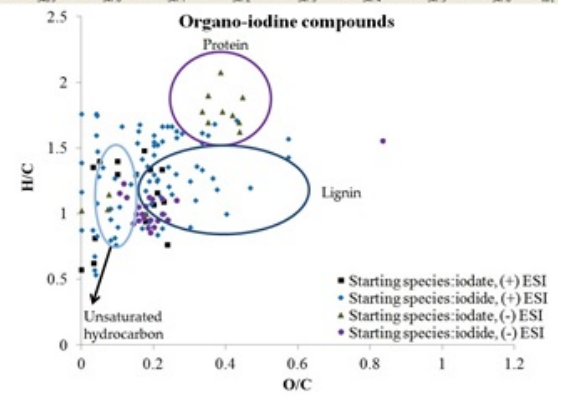

Fig. 3 
Fig. 4

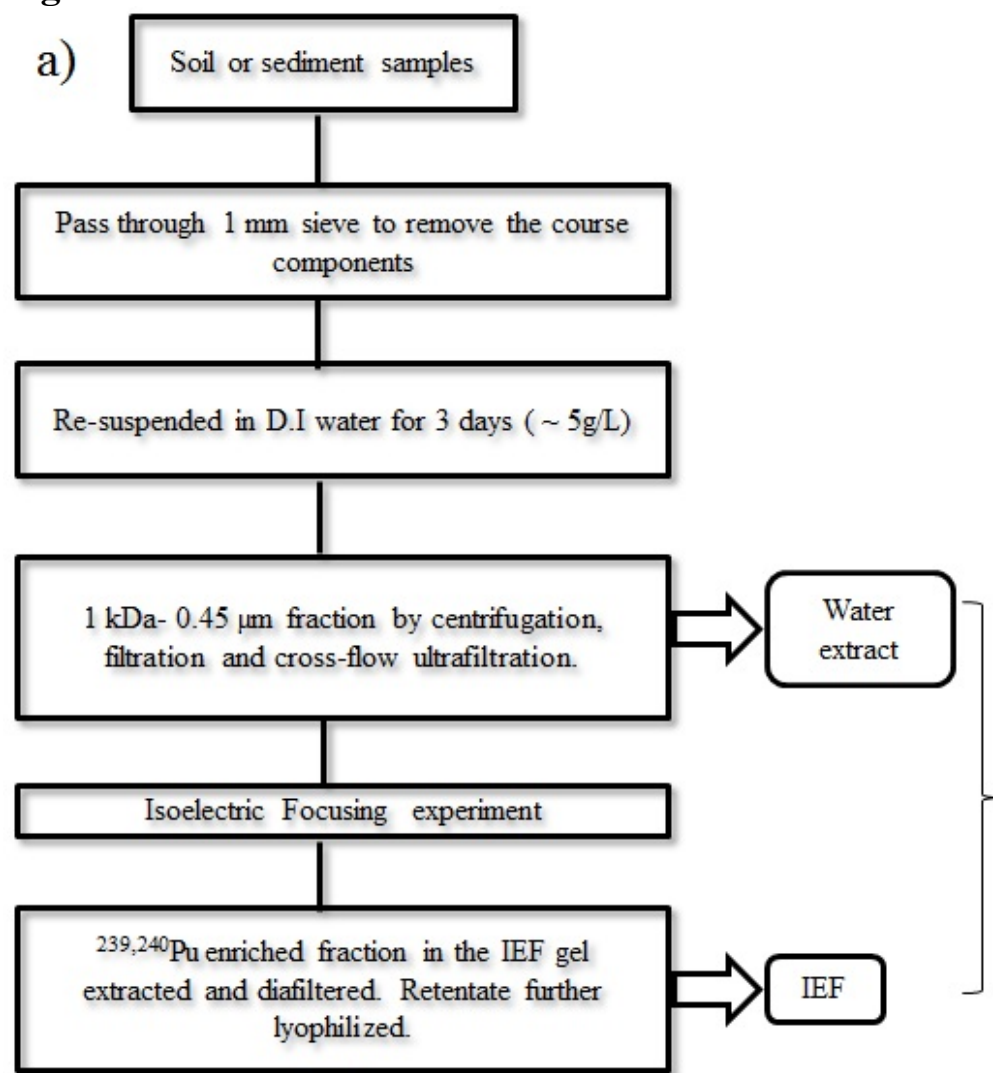

b)

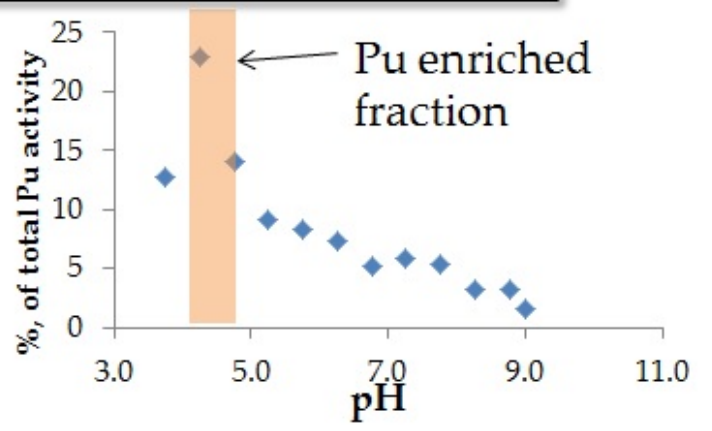

c)

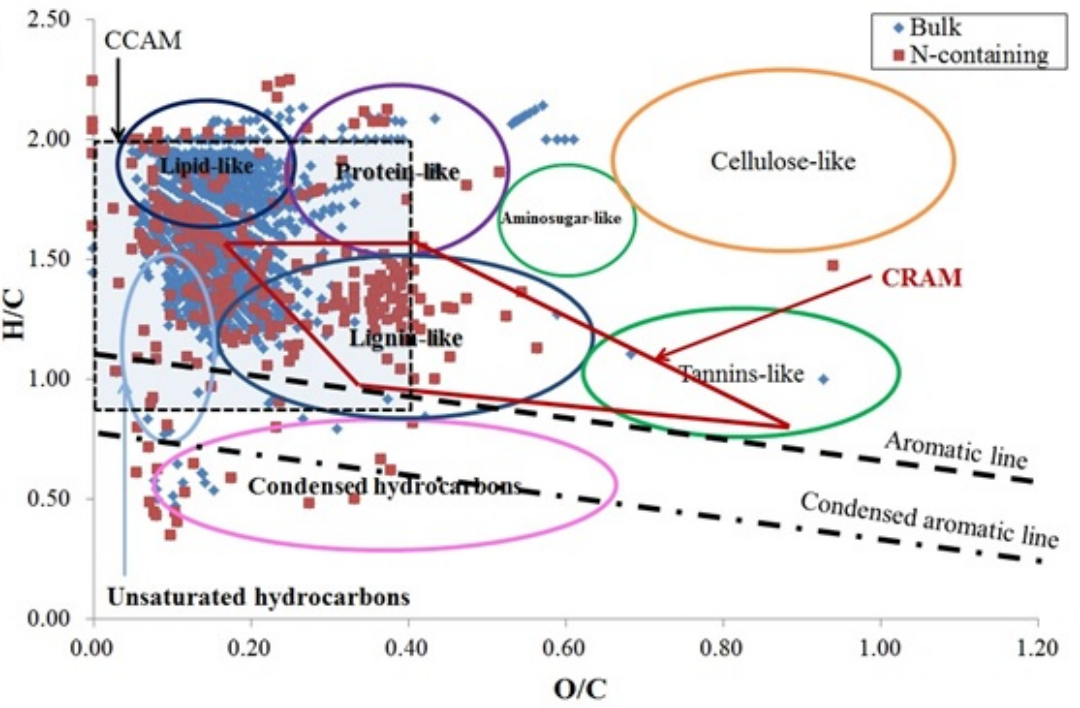

EST-FTICRMS

d)

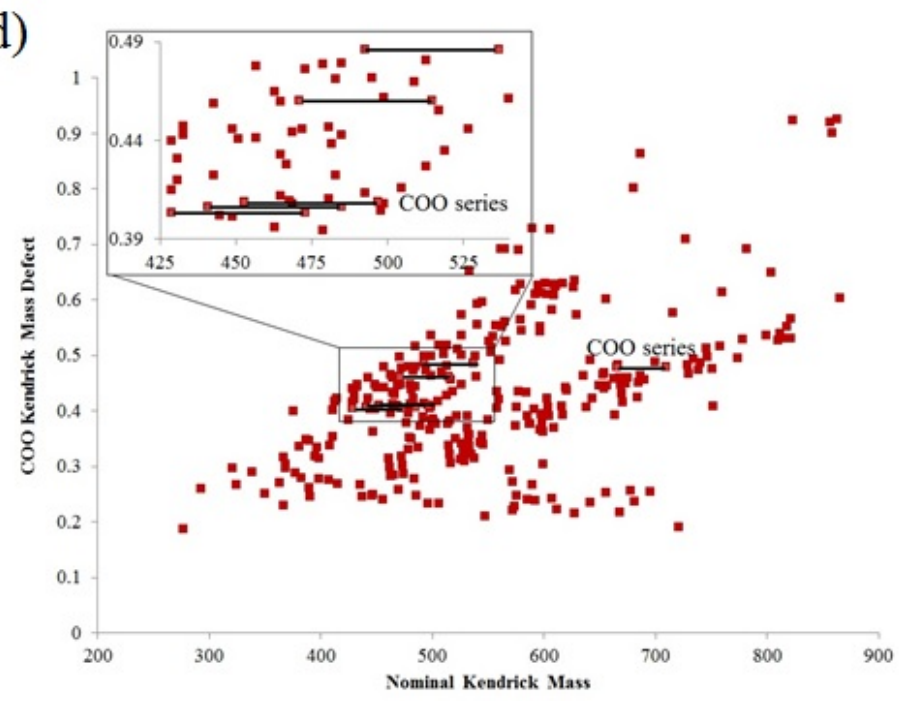

